\title{
Seasonal and interannual variations of surface climate elements over Vietnam
}

\author{
Van-Tan Phan ${ }^{1, *}$, Thanh Ngo-Duc ${ }^{2}$, Thi-Minh-Ha Ho ${ }^{1}$ \\ ${ }^{1}$ Department of Meteorology, Hanoi University of Science, 334 Nguyen Trai Street, Thanh Xuan District, Hanoi, Vietnam \\ ${ }^{2}$ Aero-Meteorological Observatory, National Hydro-Meteorological Service of Vietnam, 62 Nguyen Chi Thanh Avenue, \\ Dong Da District, Hanoi, Vietnam
}

\begin{abstract}
The 1991-2000 climate over Vietnam and the Indochina Peninsula is simulated using the Regional Climate Model version 3.0 (RegCM3). The domain of interest extends from $80^{\circ} \mathrm{E}$ to $130^{\circ} \mathrm{E}$ and $5^{\circ} \mathrm{S}$ to $40^{\circ} \mathrm{N}$. The model is driven by the ERA-40 reanalysis data as initial and lateral boundary conditions, and is forced by the Optimum Interpolation Sea Surface Temperature (OISST) data over the oceans. Validations were carried out by comparing the simulated circulation fields, $2 \mathrm{~m}$ air temperatures, and precipitation to globally available observation data, and data from 50 meteorological stations over 7 sub-regions of Vietnam. In general, the simulated patterns of the interested fields are in good agreement with observed data. Although being somewhat wetter or dryer and cooler, RegCM3 reproduces relatively well the observed annual cycle and the inter-annual variability of surface air temperature and precipitation. A large proportion of the negative biases in temperature over Vietnam is explained by the lapse rate correction process. After correction for elevation differences, the model still underestimates air temperature over most of the sub-regions. In rainy and dry seasons, RegCM3 generally underestimates and overestimates precipitation, respectively.
\end{abstract}

KEY WORDS: Climate variability $\cdot$ Model-performance measures $\cdot$ Regional climate model Resale or republication not permitted without written consent of the publisher

\section{INTRODUCTION}

To study the actual and future climate, the use of atmospheric or coupled atmospheric-ocean global models has become popular. In general, results obtained from these models presently lack regional detail due to the models' coarse resolutions. Regional Climate Models (RCM) have been developed to describe climatic patterns on a regional scale. A RCM is a limited-area model with a suitably high resolution that resolves complex topography, land use, land-sea contrast, and detailed descriptions of physical processes and then generates realistic high-resolution information coherent with the driving large-scale circulation supplied by either reanalysis data or a global general circulation model. Dickinson et al. (1989) and Giorgi \& Bates (1989) provided first assessments of the regional model simulation skill over the complex western United States terrain and studied the model's sensitivity to the use of selected physics parameterizations and lower boundary characteristics. RCMs are increasingly used in climate research and are proven to improve simulation at regional scales (e.g. Jones et al. 1995, Giorgi \& Mearns 1999, Diffenbaugh et al. 2005, Dash et al. 2006, Gao et al. 2006a,b, Solmon et al. 2006, Christensen et al. 2007, Rauscher et al. 2007, Seth et al. 2007). Jones et al. (1995) used a nested high-resolution RCM to study the climatic response to doubled carbon dioxide concentration over Europe and compared the changes against those produced by the driving global general circulation model. Gao et al. (2006b) used a RCM to investigate the role that horizontal resolution plays in the simulation of East Asia precipitation. Dash et al. (2006) demonstrated the suitability of RCMs in simulating the Indian summer monsoon circulation features and associated rainfall. Although many studies have been done for different regions of the world, RCMs have been seldom applied 
over Southeast Asia, particularly the Indochina Peninsula (but see Octaviani 2008).

Located in the eastern part of the Indochina Peninsula, Vietnam is a region with complex topography, land surface conditions, coastlines, and with a climate largely influenced by mesoscale phenomena. Northern Vietnam has a tropical monsoon climate with 4 distinguishable seasons and is influenced by the northeast monsoon originating from the Siberia Plateau, which causes cold, dry climate conditions in early winter. In late winter, the monsoon causes cold, highly humid conditions. Southern Vietnam has a rather moderate tropical climate (given the strong influence of the southwest monsoon) and is characterized by dry and rainy seasons. Under the influence of monsoon and complex topography, Vietnam is prone to natural disasters such as storms, floods and droughts. In addition, according to the Fourth Assessment Report of the Intergovernmental Panel on Climate Change (IPCC), Vietnam is one of the countries severely affected by climate change (Nicholls et al. 2007). In this study we used a RCM to investigate the processes that control the features of the climate conditions over Vietnam and adjacent areas. The regional model that we adopted is the Regional Climate Model version 3.0 (RegCM3) developed at the Abdus Salam International Centre for Theoretical Physics (ICTP) (Pal et al. 2007). RegCM3 is the third generation of a modeling framework originally described in Giorgi \& Bates (1989) and Dickinson et al. (1989) (RegCM1), and later upgraded as described in Giorgi et al. (1993a,b; RegCM2) and Giorgi \& Mearns (1999; RegCM2.5).

\section{MODEL AND DATA}

RegCM3 is a primitive equation, hydrostatic, compressible, limited-area model with a sigma $(\sigma)$ vertical coordinate. The model runs with 18 vertical $\sigma$-levels, in which 6 levels are under $850 \mathrm{mb}$ in the planetary boundary layer. The top layer is at $70 \mathrm{mb}$.

The domain size extends from $80^{\circ} \mathrm{E}$ to $130^{\circ} \mathrm{E}$ and from $5^{\circ} \mathrm{S}$ to $40^{\circ} \mathrm{N}$ with a horizontal resolution of $54 \mathrm{~km}$ for both east-west and north-south directions. The normal Mercator conformal projection is used in this study (Fig. 1A).

The data used as initial and time-dependent boundary conditions for RegCM3 are the ERA-40 reanalysis data

\section{A}

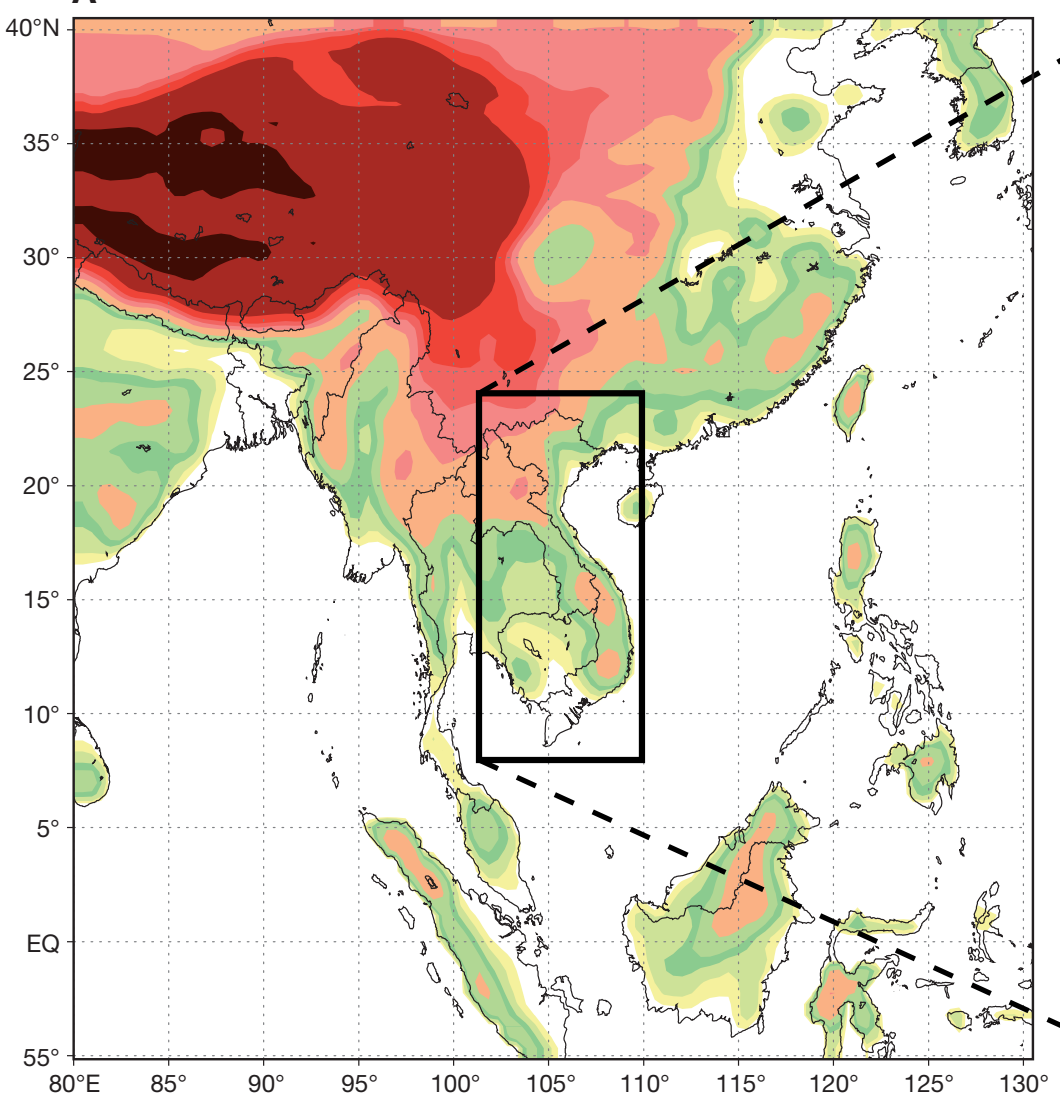

B

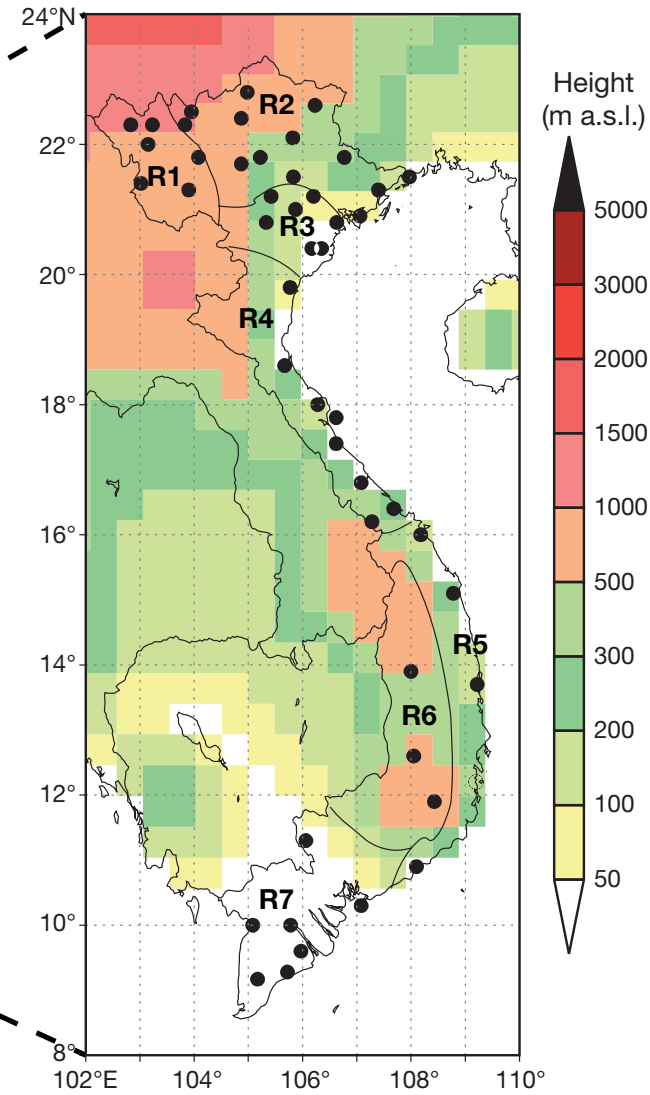

Fig. 1. (A) Topography of the model domain, and (B) locations of the meteorological stations (•) and the 7 climatological sub-regions (R1-R7) of Vietnam 
(http://users.ictp.it/ pubregcm/RegCM3/globedat.htm) with horizontal resolution of $2.5 \times 2.5^{\circ}$ and $6 \mathrm{hr}$ time interval (Uppala et al. 2005). Over the oceans, RegCM3 is forced by the Optimum Interpolation Sea Surface Temperature (OISST) data, which is available on a $1.0 \times 1.0^{\circ}$ grid mesh and provided by NOAA (Office of Oceanic and Atmospheric Research, Earth System Research Laboratory, Physical Science Division), Boulder, Colorado, USA, from their website at www.cdc.noaa.gov (Reynolds et al. 2002). The model is integrated continuously from 00:00 h UTC December 01, 1990 to 00:00 h UTC January 01, 2001. The first month (December 1990) is treated as the spin-up time.

We conducted sensitivity tests with different configurations of RegCM3 to select the suitable parameterizations for Vietnam. Exchanges of energy, moisture, and momentum between the land surface and the atmosphere were computed using the Biosphere-Atmosphere Transfer Scheme (BATS) (Dickinson et al. 1993). The radiative transfer scheme of the NCAR Community Climate Model (CCM3) (Kiehl et al. 1996) is used in RegCM3, and includes the effect of different greenhouse gases, cloud water, cloud ice and atmosphere. Resolvable (or large-scale) precipitation is represented using the sub-grid explicit moisture (SUBEX) scheme (Pal et al. 2000). Convective (sub-grid scale) precipitation processes are represented using the cumulus parameterization scheme, which describes the effects of sub-grid scale convective clouds that produce grid-scale heating and precipitation in terms of the grid-scale prognostic variables. For convective parameterizations, we ran 4 integrations using different schemes: (1) Kuo (Kuo77; Anthes 1977), (2) MIT-Emanuel (Ema91; Emanuel 1991, Emanuel \& Zivkovic-Rothman 1999), (3) Grell (Grell 1993) using the Arakawa-Schubert closure assumption (AS74; Arakawa \& Schubert 1974), and (4) Grell using the Fritsch-Chappell closure assumption (FC80; Fritsch \& Chappell 1980). Results show that Kuo77 and FC80 give highest and lowest $2 \mathrm{~m}$ temperatures respectively over the simulated domain (data not shown), and produce underestimated and overestimated precipitation, respectively. Over the South China Sea, Ema91 reproduces the largest rainfall area compared to the other schemes, while it creates a significant dry region over the equator. In this study, we employ the Grell scheme with the AS74 closure assumption.

Various datasets are used to evaluate the quality of the simulations. The simulated circulations in the interior of the interested domain are compared with the ERA-40 data. Precipitation and surface air temperature are validated against the Climatic Research Unit (CRU) (UK) data (New et al. 1999, New et al. 2000). The CRU data set is a high-resolution $\left(0.5^{\circ}\right)$ monthly product over continents that includes for the 1901-2000 period a gauge-only estimate of precipitation and tempera- ture, as well as other near surface climatic variables. Moreover, monthly mean surface air temperature and monthly accumulative precipitation from 50 meteorological stations over Vietnam were compared with the RegCM3's results.

\section{RESULTS AND DISCUSSION}

\subsection{Regional circulation patterns}

Comparison of the $10 \mathrm{yr}$ averages (1991-2000) of geo-potential height and wind fields at $500 \mathrm{hPa}$ for the 4 typical months January, April, July and October shows the consistency of RegCM3 with ERA-40 for January and July (Fig. 2). RegCM3 reproduces well the patterns given by ERA-40, in both spatial distribution and magnitude. In the transitional period from autumn to winter (October) and in the middle of winter (January) when cold air masses penetrate to the south, there is a high pressure region located over China originating from the Siberian plateau. In summer (July), there is a typical low pressure region located over the Tibetan Plateau.

\subsection{Surface air temperature and precipitation}

Fig. 3 gives the monthly mean of observed and simulated surface air temperatures averaged over the 1991-2000 period for January, April, July, and October for land only. The main features of spatial distribution of surface air temperature simulated by RegCM3 agree well with the CRU data for the 4 mo. However, the RegCM3 simulation shows a tendency to underestimate temperature by 1 to $2^{\circ} \mathrm{C}$ with CRU data (see particularly the Indochina Peninsula in April and July). The underestimations of temperature in RegCM3 were also reported in previous studies for other regions (e.g. Gallée et al. 2004, Rauscher et al. 2006, Seth et al. 2007) and other RCMs (e.g. Nicolini et al. 2002, Qian et al. 2003, Seth \& Rojas 2003). We will analyze in more detail this cold bias in the next section, where RegCM3 temperature is compared to observed data from different meteorological stations over Vietnam.

Due to the complex nature of the monsoon processes over South East Asia, climate models have considerable difficulty simulating the characteristics of precipitation over the region (Webster et al. 1998, Park \& Hong 2004, Ramel et al. 2006). Comparison between the simulated and observed precipitation fields shows that RegCM3 captures general rainfall patterns, although considerable differences exist (Fig. 4). In some regions, the RegCM3 simulation compares favorably with observed data (e.g. over East China in April, over 

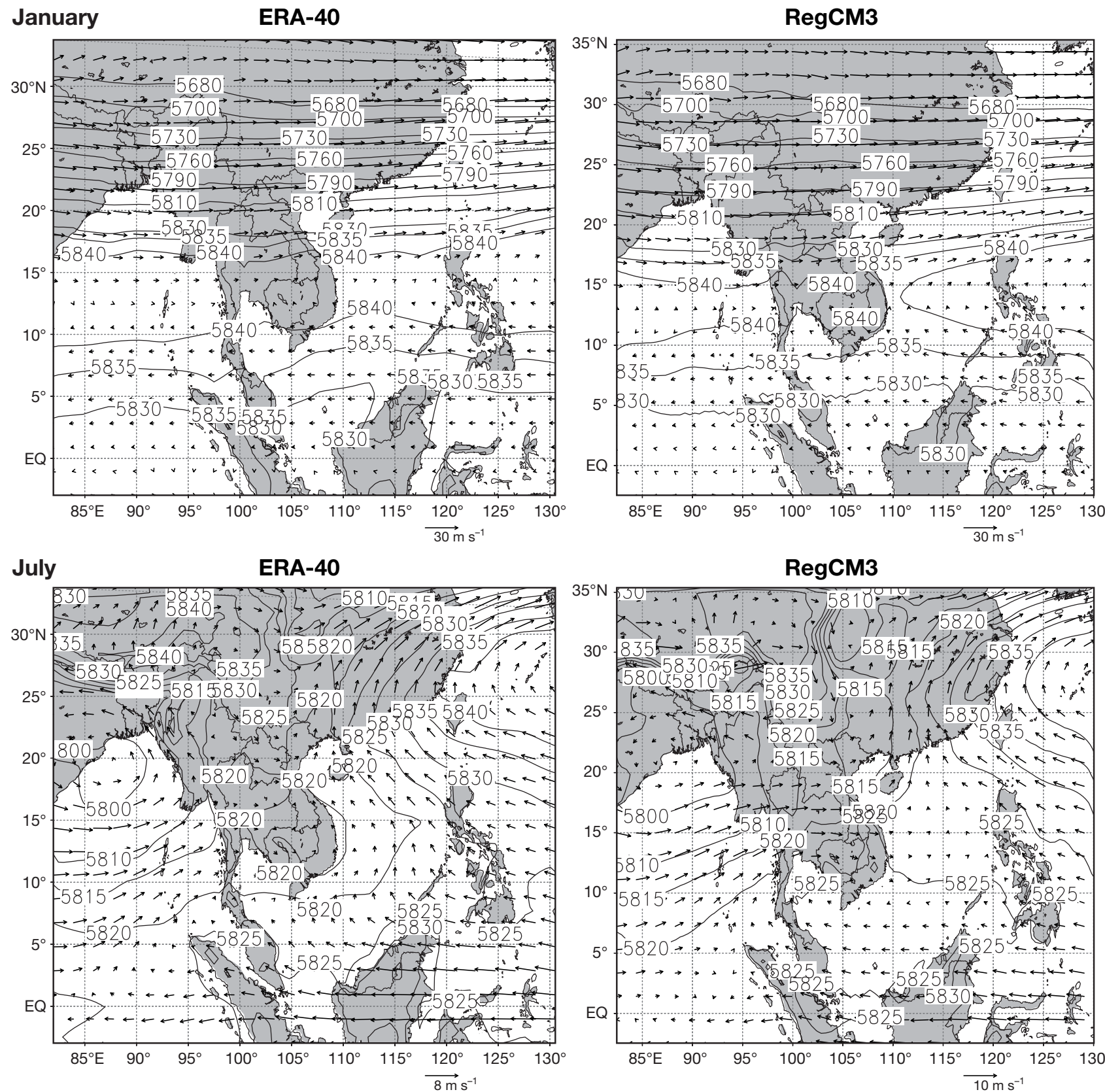

RegCM3

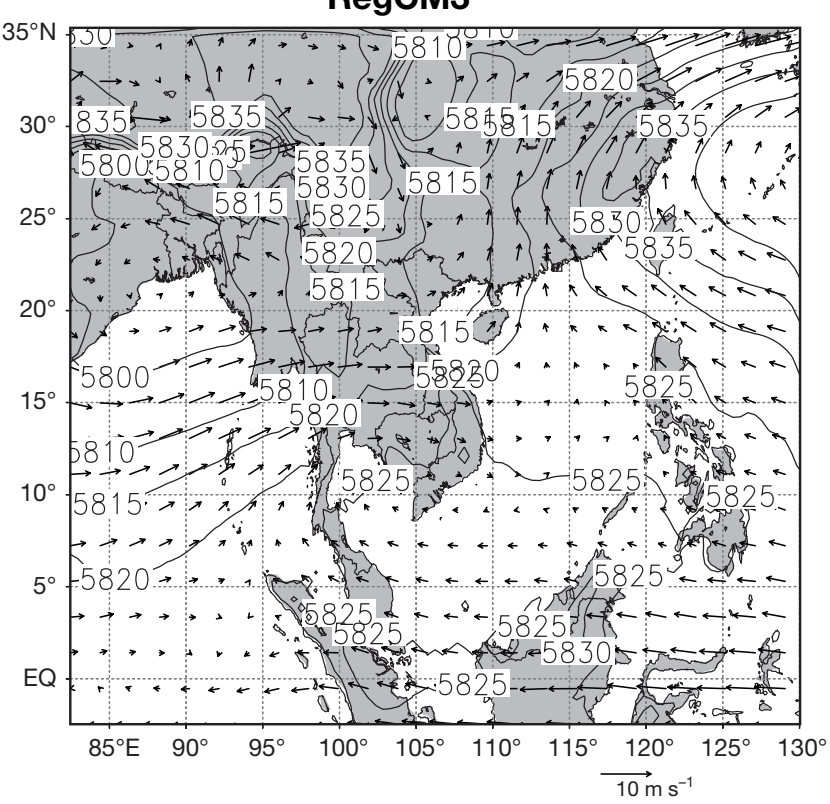

Fig. 2. 1991-2000 average geopotential height at $500 \mathrm{hPa}$ from (left) ERA-40 and (right) RegCM3 simulation in January (top) and July (bottom). Wind speed and direction at $500 \mathrm{hPa}$ are superimposed (arrows)

Vietnam in July, October), while in other regions it compares less favorably (e.g. over East India in January). Together with the underestimation of temperature, there is a tendency for the model to simulate excessive precipitation, especially at the maximum cores located over Myanmar, the Bay of Bengal, and the Philippine Archipelago areas. This can be partly explained by the fact that: (1) the RegCM3 tends to have too strong precipitation for some regions (Giorgi
\& Shields 1999); and (2) since the observation stations are usually located in the valleys and plains, the CRU gridded observation data can well underestimate the precipitation over mountains or have bias. In addition, because of the effects of wind, wetting losses, evaporation, and form of precipitation, a precipitation measurement may underestimate the actual precipitation amount by factors of up to $40 \%$ (Legates \& Willmott 1990). 

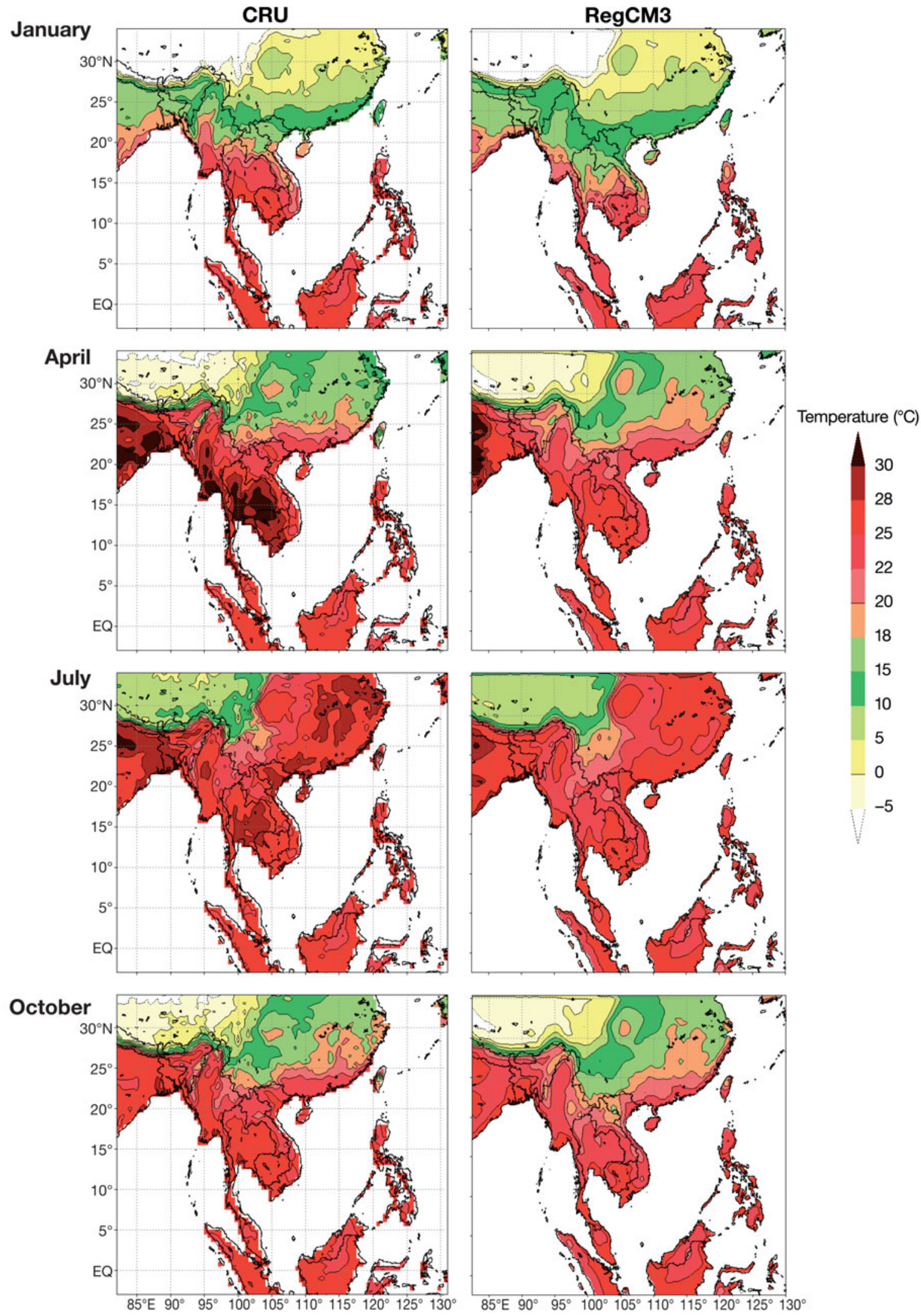

$85^{\circ} \mathrm{E} 90^{\circ} 95^{\circ} 100^{\circ} 105^{\circ} 110^{\circ} 115^{\circ} 120^{\circ} 125^{\circ} 130^{\circ}$

Fig. 3. 1991-2000 average surface air temperature $\left({ }^{\circ} \mathrm{C}\right)$ from (left) CRU data and (right) RegCM3 simulation in January, April, July and October 

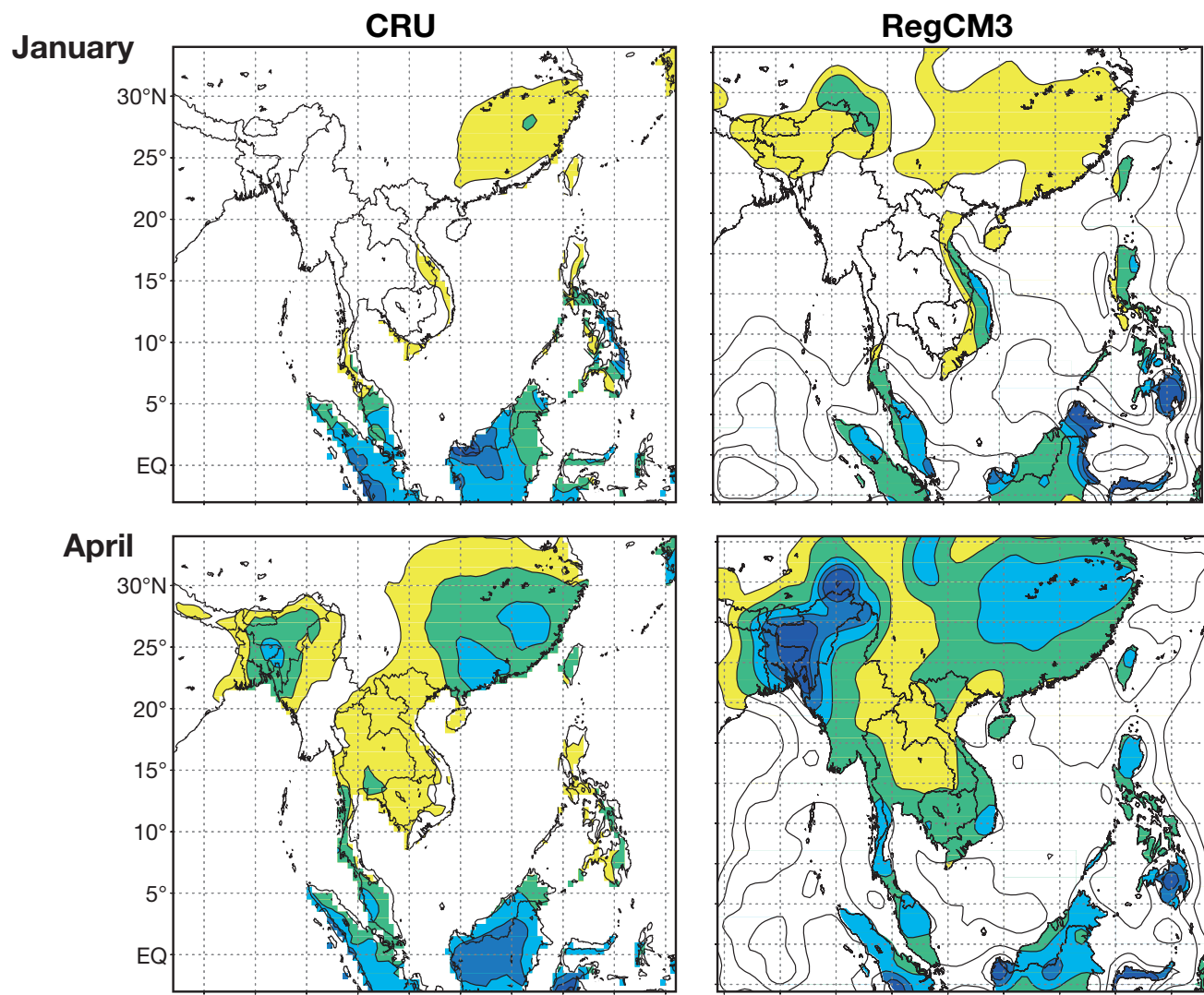

Precipitation

(× $100 \mathrm{~mm} \mathrm{mo}^{-1}$ )

July
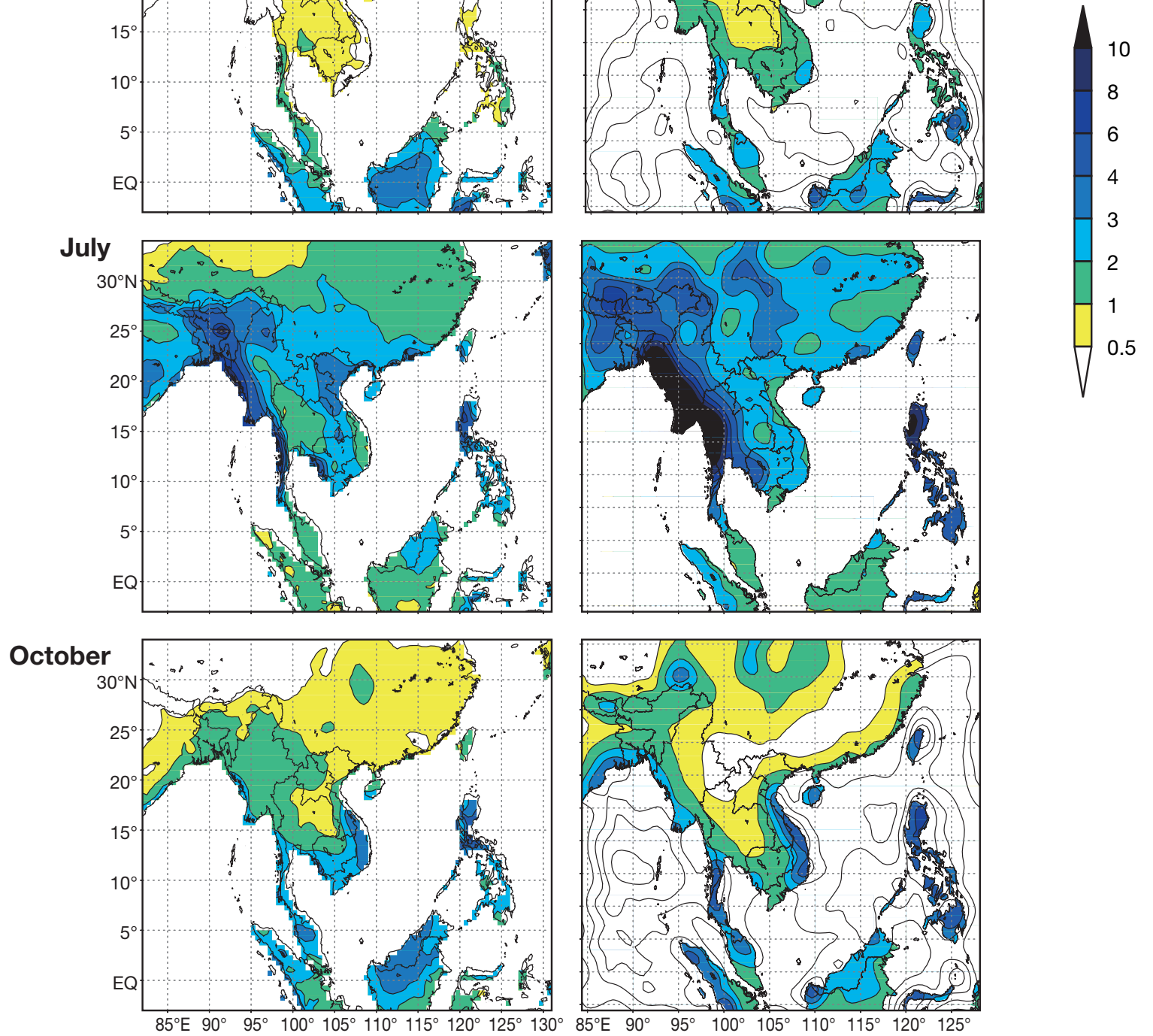

Fig. 4. 1991-2000 average precipitation ( $\mathrm{mm} \mathrm{mo}^{-1}$ ) from (left) CRU data and (right) RegCM3 simulation in January, April, July and October 


\subsection{Validation of the model for Vietnam}

To estimate the performance of RegCM3 in reproducing temperature and precipitation over Vietnam, monthly mean surface air temperature and accumulated precipitation from 50 meteorological stations over 7 geographical and climatological sub-regions (Fig. 1) were collected from January 1991 to December 2000.

The Vietnam area is small $\left(329560 \mathrm{~km}^{2}\right)$ but its spatial classification is complicated, resulting from the interaction between monsoon circulation and the topography. For example, the R1 and R2 regions are only separated by the Hoang Lien Son mountain range (longitude $103.5^{\circ} \mathrm{E} \sim 104.5^{\circ} \mathrm{E}$, latitude $21.5^{\circ} \mathrm{N} 22.5^{\circ} \mathrm{N}$ ); however, the rainfall genesis mechanisms in the 2 regions are quite different: in the summer, R2 is directly affected by tropical cyclones while R1 is mainly affected by the southwest monsoon; in the winter, R2 is often affected by the cold front while R1 is not, although the temperature of both regions decreases with the cold air mass penetration.

Of the several studies classifying Vietnam into climatological sub-regions, the 7 regions classsified by Nguyen \& Nguyen (2004) (Fig. 1) are at present widely accepted by the Vietnamese climatological community.

In general, RegCM3 systematically underestimates surface air temperature over most of the sub-regions (except R6) in all months; the largest difference is $-5.1^{\circ} \mathrm{C}$ over the region R1 in December (Fig. 5). The best-simulated results are in the $\mathrm{R} 6$ and $\mathrm{R} 7$ areas, with biases ranging from -0.1 to $1.7^{\circ} \mathrm{C}$ and from -1.3 to $0.2^{\circ} \mathrm{C}$, respectively. Over the northern and central subregions, large biases occurred in the warm period and in the early months of winter. Average biases over the whole country show negative values and range from $-0.2^{\circ} \mathrm{C}$ in March down to $-2.5^{\circ} \mathrm{C}$ in December.

Bias frequency distributions of monthly surface air temperature are significantly different among subregions (Fig. 6). Standard deviations (used to measure the distribution spread) are 2.0, 2.7, 2.2, 2.0, 1.2, 2.9 and $0.8^{\circ} \mathrm{C}$ for R1, R2, R3, R4, R5, R6 and R7, respectively. Except for the R6 area, where the frequency of warm biases is greater than that of cold biases $(56 \%$ compared to $44 \%$ ), RegCM3 produces overall about $70 \%$ negative bias cases.

The cold biases that exist over most of the sub-regions originate partly from the difference between the elevation of the observed stations and the elevation of the model grid. Table 1 gives the mean elevation of the observed station $\left(\mathrm{H}_{\mathrm{O}}\right)$ and the model grid $\left(\mathrm{H}_{\mathrm{M}}\right)$ for each sub-region. Differences in temperature $(\Delta T)$ due to differences in elevation $\left(\mathrm{H}_{\mathrm{M}}-\mathrm{H}_{\mathrm{O}}\right)$ are calculated based on the environmental lapse rate coefficient $\gamma=-0.65^{\circ} \mathrm{C}$ $100 \mathrm{~m}^{-1}$. Table 1 shows that a large part of the cold biases can be explained from the lapse rate correction process. After correcting for the elevation difference, RegCM3 still underestimates air temperature over most sub-regions ( $\Delta T>T_{\mathrm{RegCM}}-T_{\mathrm{OBS}}$ ) (Table 1). Particularly, although RegCM3 shows a temperature overestimation for the sub-region R6, after taking into account the lapse rate correction RegCM3 underestimates the temperature for this region by $\sim 0.14^{\circ} \mathrm{C}$.

Annual cycles of averaged monthly precipitation for the seven sub-regions are shown in Fig. 5. Although RegCM3 captures the annual cycles of precipitation, the simulated signals over the sub-regions have a tendency to be underestimated in the rainy season $(\sim 13 \%)$ and overestimated in the dry season $(\sim 103 \%)$. The model biases of precipitation are large and significantly different among the sub-regions. RegCM3 produces the most realistic results over the R4 and R6 areas in the rainy season, but produces large dry biases over the R1 and R2 areas in the summer months (June to August) and over the R7 area in the whole rainy season (May to October). A particular case is the R5 sub-region where precipitation is strongly overestimated by the model. In winter, substantial overestimations of precipitation are identified for all the subregions.

Inter-annual variations in surface air temperature over all sub-regions are well represented by RegCM3 (Fig. 7; lapse rate correction not been applied). The mean model errors within a given sub-region are stable from year to year. Except for the sub-region R6 where temperature is overestimated, annual values of simulated temperature for other sub-regions are systematically underestimated, from about $0.5^{\circ} \mathrm{C}(\mathrm{R} 6)$ to about $3.1^{\circ} \mathrm{C}$ (R1 and $\left.\mathrm{R} 4\right)$. The modelled and observed data both show that 1998 was a particularly hot year for all the 7 sub-regions and for Vietnam. This is the year in which Vietnam and many other regions of the world were highly influenced by the strong 1997/1998 El Niño event.

Inter-annual variations in simulated precipitation are generally in agreement with observed precipitation (Fig. 7). However, mean biases are different from year to year and from sub-region to sub-region. Annual mean precipitation values simulated by RegCM3 have a tendency to be overestimated for the R4, R5, R6 subregions and to be underestimated for the R1, R2 and R7 sub-regions. Particularly large wet biases (overestimated) are identified for the R7 area. Over the R3 area and over the whole of Vietnam, annual precipitation values are reasonably well represented.

\section{CONCLUSIONS}

In this study, the RegCM3 integration for the 1991-2000 period was examined to determine the model's capability in simulating the observed annual 

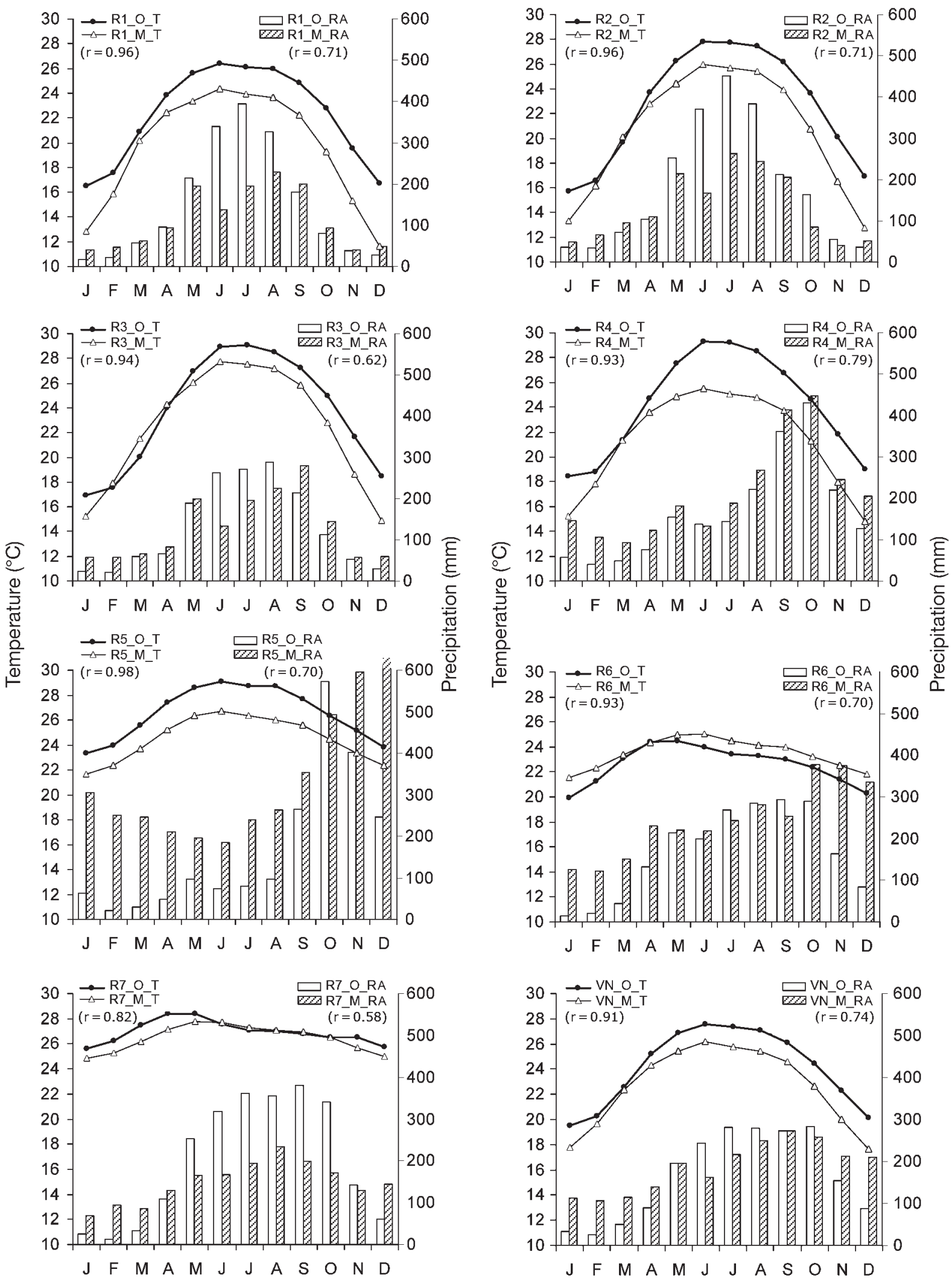

Fig. 5. Monthly 1991-2000 mean surface air temperature $\left({ }^{\circ} \mathrm{C}\right)$ and precipitation $\left(\mathrm{mm} \mathrm{mo}^{-1}\right)$ averaged over the 7 sub-regions $(\mathrm{R} 1-\mathrm{R} 7)$ and the entire Vietnam territory (VN). O: observed, M: RegCM3, RA: rainfall, T: temperature.Correlation coefficients (r) are also given 


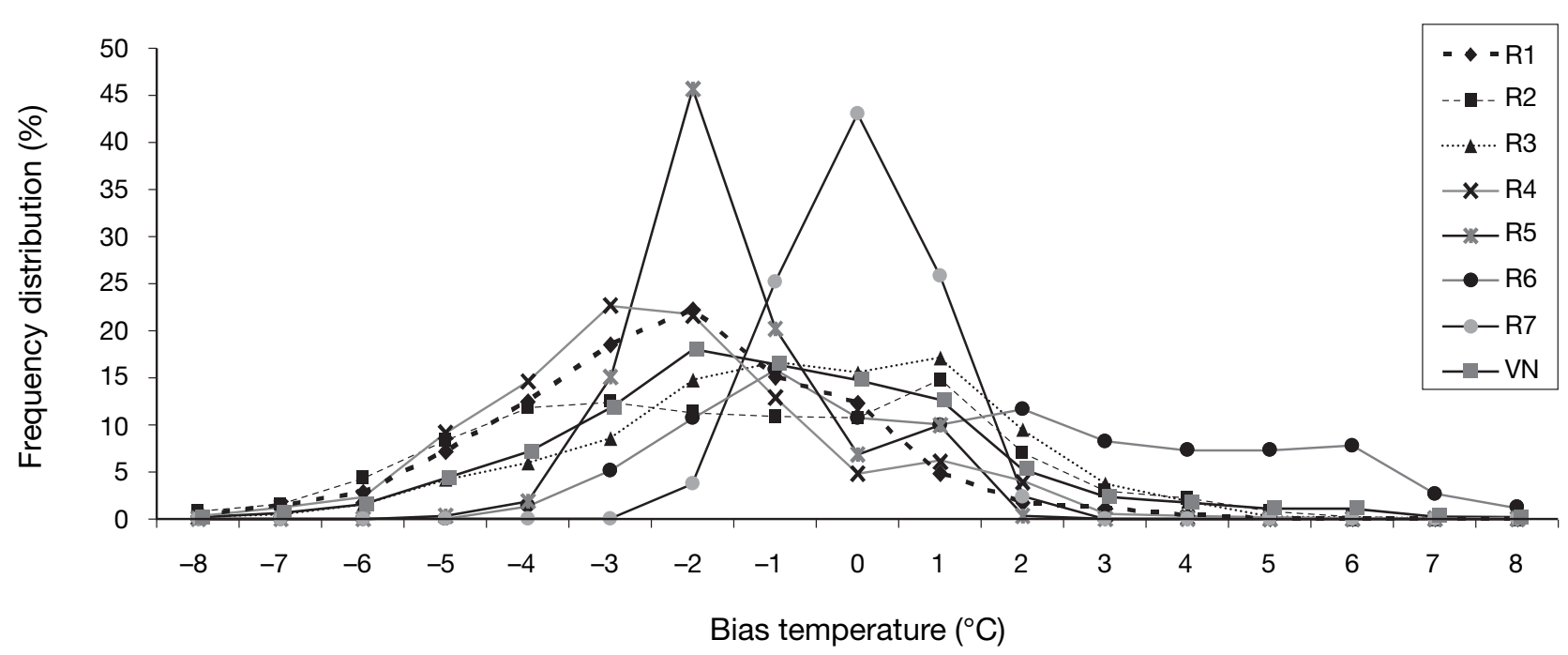

Fig. 6. Bias frequency distributions (\%) of monthly surface air temperature $\left({ }^{\circ} \mathrm{C}\right)$ over the 7 sub-regions (R1-R7) and the entire Vietnam territory $(\mathrm{VN})$

Table 1. Mean elevation of the observed stations $\left(\mathrm{H}_{\mathrm{O}}\right)$ and the model $\left(\mathrm{H}_{\mathrm{M}}\right)$ for the 7 sub-regions (R1 to R7). Difference in temperature $(\Delta T)$ due to difference in elevation $\left(\mathrm{H}_{\mathrm{M}}-\mathrm{H}_{\mathrm{O}}\right)$ is calculated based on the environmental lapse rate coefficient $\gamma=-0.65^{\circ} \mathrm{C} 100 \mathrm{~m}^{-1}$. Difference between mean model temperature and mean observed temperature ( $\left.T_{\mathrm{RegCM}}-T_{\mathrm{OBS}}\right)$ is also given

\begin{tabular}{|rrrccc|}
\hline & $\mathrm{H}_{\mathrm{O}}(\mathrm{m})$ & $\mathrm{H}_{\mathrm{M}}(\mathrm{m})$ & $\begin{array}{c}\mathrm{H}_{\mathrm{M}}-\mathrm{H}_{\mathrm{O}}(\mathrm{m}) \\
\left({ }^{\circ} \mathrm{C}\right)\end{array}$ & $\begin{array}{c}\Delta T=\left(\mathrm{H}_{\mathrm{M}}-\mathrm{H}_{\mathrm{O}}\right) \times \gamma \\
\left({ }^{\circ} \mathrm{C}\right)\end{array}$ & $T_{\mathrm{RegCM}}-T_{\mathrm{OBS}}$ \\
\hline $\mathrm{R} 1$ & 407.9 & 704.1 & 296.2 & -1.93 & -2.67 \\
$\mathrm{R} 2$ & 158.1 & 520.2 & 362.1 & -2.35 & -2.00 \\
$\mathrm{R} 3$ & 19.6 & 103.1 & 83.4 & -0.54 & -1.24 \\
$\mathrm{R} 4$ & 20.0 & 243.6 & 223.6 & -1.45 & -2.85 \\
$\mathrm{R} 5$ & 7.5 & 177.8 & 170.3 & -1.11 & -2.03 \\
$\mathrm{R} 6$ & 679.7 & 516.3 & -163.4 & 1.06 & 0.92 \\
$\mathrm{R} 7$ & 31.7 & 69.0 & 37.2 & -0.24 & -0.5 \\
\hline
\end{tabular}

At the regional scale (Vietnam and adjacent areas), there is a tendency for RegCM3 to simulate excessive precipitation, especially at the maximum cores located over Myanmar, the Bay of Bengal, and the Philippine Archipelago area. At a smaller scale, over the 7 sub-regions of Vietnam, RegCM3 generally underestimates $(\sim 13 \%)$ and overestimates ( 103\%) precipitation in rainy and dry seasons, respectively.

The horizontal resolution of numerical integration used in this study is $54 \mathrm{~km}$. Sensitivity tests were done for different resolutions: 30, 45, 54, and $60 \mathrm{~km}$ (data not shown). The model

cycle, seasonal and inter-annual variability of precipitation and surface air temperature over Vietnam, Indochina and adjacent areas. The results showed that RegCM3 is able to reproduce the regional circulation patterns and the spatial and time distributions of surface air temperature, as well as precipitation, over the model domain. However, RegCM3 systematically produces cold biases in temperature. Analysis of all the modelled and observed monthly values of the 1991-2000 period shows that, except for the R6 area, where the frequency of warm biases is greater than that of cold biases, RegCM3 produces overall about $70 \%$ negative bias cases. A large proportion of the negative biases are explained by the lapse rate correction process. After correction for elevation differences, the model still underestimates air temperature over most sub-regions. outputs show that temperature at $2 \mathrm{~m}$ varies negligibly with these resolutions. For rainfall, we obtained the same pattern but with more spatial details for higher resolutions.

Although significant differences between the RegCM3 simulated- and station observed-climate parameters remain, this study is one of the first attempts to show that RegCM3 can be used to reproduce the characteristics of some climate elements of Indochina and other adjacent areas in general and of Vietnam in particular. The results suggest that RegCM3 is adequate for studies in this region, e.g. seasonal forecasting and climate change. Necessary parameterizations and calibrations, as well as running longer simulations and higher resolutions are interesting topics to investigate in the future. 

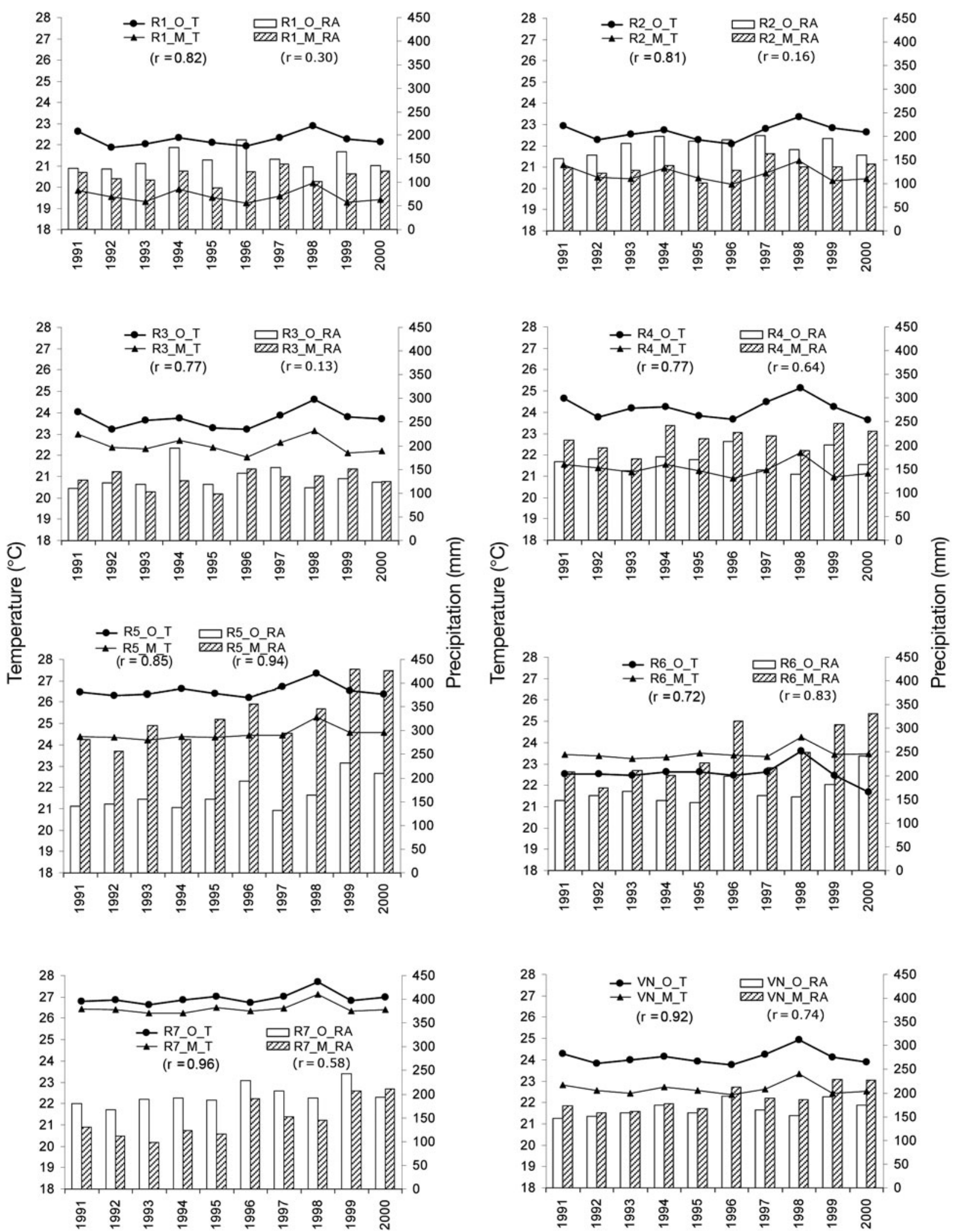

Fig. 7. Interannual variations of surface air temperature $\left({ }^{\circ} \mathrm{C}\right)$ and precipitation $\left(\mathrm{mm} \mathrm{mo} \mathrm{m}^{-1}\right)$ averaged over the 7 sub-regions (R1-R7) and the entire Vietnam territory (VN). O: observed, M: RegCM3, RA: rainfall, T: temperature. Correlation coefficients (r) are also given 


\section{LITERATURE CITED}

Arakawa A, Schubert WH (1974) Interaction of a cumulus cloud ensemble with the large-scale environment: Part 1. J Atmos Sci 31:674-701

Anthes RA (1977) A cumulus parameterization scheme utilizing a one-dimensional cloud model. Mon Weather Rev 105:270-286

Christensen JH, Hewitson B, Busuioc A, Chen A and others (2007) Regional climate projections. In: Solomon SD, Qin M, Manning Z, Chen $\mathrm{M}$ and others (eds) Climate change 2007: the physical science basis. Contribution of Working Group I to the Fourth Assessment Report of the Intergovernmental Panel on Climate Change. Cambridge University Press, Cambridge

> Dash SK, Shekhar MS, Singh GP (2006) Simulation of Indian summer monsoon circulation and rainfall using RegCM3. Theor Appl Climatol 86:161-172.

Dickinson RE, Errico RM, Giorgi F, Bates G (1989) A regional climate model for the western United States. Clim Change 15:383-422

Dickinson RE, Henderson-Sellers A, Kennedy PJ (1993) Biosphere-Atmosphere Transfer Scheme (BATS) version 1E as coupled to the NCAR Community Climate Model. NCAR Tech. Note. National Center for Atmospheric Research, Boulder, $\mathrm{CO}$

Diffenbaugh N, Pal J, Trapp R, Giorgi F (2005) Fine-scale processes regulate the response of extreme events to global climate change. Proc Natl Acad Sci 102:15774-15778

Emanuel KA (1991) A scheme for representing cumulus convection in large-scale models. J Atmos Sci 48:2313-2335

- Emanuel KA, Zivkovic-Rothman M (1999) Development and evaluation of a convection scheme for use in climate models. J Atmos Sci 56:1766-1782

Fritsch JM, Chappell CF (1980) Numerical prediction of convectively driven mesoscale pressure systems. I. Convective parameterization. J Atmos Sci 37:1722-1733

Gallée H, Moufouma-Okia W, Bechtold P, Brasseur O and others (2004) A high-resolution simulation of a West African rainy season using a regional climate model. J Geophys Res 109:D05108, doi:10.1029/2003JD004020

Gao XJ, Pal JS, Giorgi F (2006a) Projected changes in mean and extreme precipitation over the Mediterranean region from a high-resolution double nested RCM simulation. Geophys Res Lett 33:L03706, doi:10.1029/2005GL024954

Gao XJ, Xu Y, Zhao ZC, Pal JS, Giorgi F (2006b) On the role of resolution and topography in the simulation of East Asia precipitation. Theor Appl Climatol 86:173-185

Giorgi F, Bates GT (1989) The climatological skill of a regional climate model over complex terrain. Mon Weather Rev 117:2325-2347

Giorgi F, Marinucci MR, Bates GT (1993a) Development of a second-generation regional climate model (RegCM2). I. Boundary-layer and radiative transfer processes. Mon Weather Rev 121:2749-2813

Giorgi F, Marinucci MR, Bates GT, De Canio G (1993b) Development of a second generation regional climate model (RegCM2). II. Convective processes and assimilation of lateral boundary conditions. Mon Weather Rev 121: $2814-2832$

> Giorgi F, Mearns LO (1999) Introduction to special section: regional climate modelling revisited. J Geophys Res 104: 6335-6352

- Giorgi F, Shields C (1999) Tests of precipitation parameterizations available in the latest version of the NCAR regional climate model (RegCM) over the Continental US. J Geophys Res 104:6353-6375
Grell GA (1993) Prognostic evaluation of assumptions used by cumulus parameterization. Mon Weather Rev 121: 764-787

Jones RG, Murphy JM, Noguer M (1995) Simulation of climate change over Europe using a nested regional-climate model. I. Assessment of control climate, including sensitivity to location of boundaries. QJR Meteorol Soc 121: $1413-1450$

Kiehl JT, James JH, Gordon BB, Byron AB and others (1996) Description of the NCAR Community Climate Model (CCM3). Boulder, Colorado: Tech. Note, NCAR/TN-420+ STR, 152 pp.

> Legates DR, Willmott CJ (1990) Mean seasonal and spatial variability in gauge-corrected, global precipitation. Int J Climatol 10:111-127

New M, Hulme M, Jones P (1999) Representing twentiethcentury space-time climate variability. I. Development of a 1961-90 mean monthly terrestrial climatology. J Clim 12: 829-856

> New M, Hulme M, Jones P (2000) Representing twentiethcentery space-time climate variability. II. Development of a 1901-90 mean monthly grids of terrestrial surface climate. J Clim 13:2217-2238

Nguyen DN, Nguyen TH (2004) Climate and climate resources of Vietnam. Agriculture Publisher, Hanoi

Nicholls RJ, Wong PP, Burkett VR, Codignotto JO and others (2007) Coastal systems and low-lying areas. In: Parry ML, Canziani OF, Palutikof JP, van der Linden PJ, Hanson CE (eds) Climate change 2007: impacts, adaptation and vulnerability. Contribution of Working Group II to the Fourth Assessment Report of the Intergovernmental Panel on Climate Change. Cambridge University Press, Cambridge, p 315-356

Nicolini M, Salio P, Katzfey JJ, McGregor JL, Saulo AC (2002) January and July regional climate simulation over South America. J Geophys Res 107(D22):4637, doi:10.1029/2001 JD000736

Octanviani M (2008) Application of regional climate model RegCM3 to Thailand and performance evaluation. MPhil thesis, The Joint Graduate School of Energy and Environment at King Mongkut's University of Technology, Thonburi, Thailand

Pal JS, Small EE, Eltahir EAB (2000) Simulation of regional scale water and energy budgets: influence of a new moist physics scheme within RegCM. J Geophys Res 105: 29579-29594

Pal JS, Giorgi F, Bi X, Elguindi N and others (2007) Regional climate modeling for the developing world: the ICTP RegCM3 and RegCNET. Bull Am Meteorol Soc 88: 1395-1409

Park S, Hong S (2004) The role of surface boundary forcing over South Asia in the Indian summer monsoon circulation: A regional climate model sensitivity study. Geophys Res Lett 31:L12112. doi:10.1029/2004GL019729

- Qian JH, Seth A, Zebiak S (2003) Reinitialized versus continuous simulations for regional climate downscaling. Mon Weather Rev 131:2857-2874

Ramel R, Gallee H, Messager C (2006) On the northward shift of the West African monsoon. Clim Dyn 26:429-440

Rauscher SA, Seth A, Qian JH, Camargo SJ (2006) Regional climate model domain choice in the tropics based on process considerations. Theor Appl Climatol 86:229-246

> Rauscher SA, Seth A, Liebmann B, Qian JH, Carmargo SJ (2007) Regional climate model-simulated timing and character of seasonal rains in South America. Mon Weather Rev 135:2642-2657

Reynolds RW, Rayner NA, Smith TM, Stokes DC, Wang W 
(2002) An improved in situ and satellite SST analysis for climate. J Clim 15:1609-1625

Seth A, Rojas M (2003) Simulation and sensitivity in a nested modeling system for South America. I. Reanalyses boundary forcing. J Clim 16:2437-2453

Seth A, Rauscher SA, Carmago SJ, Qian JH, Pal JS (2007) RegCM3 regional climatologies using reanalysis and ECHAM global model driving fields. Clim Dyn 28: 461-480

Solmon F, Giorgi F, Liousse C (2006) Aerosol modeling for

Editorial responsibility: Filippo Giorgi,

Trieste, Italy regional climate studies: Application to anthropogenic particles and evaluation over a European/African domain. Tellus 58:51-72

Uppala SM, Kallberg PW, Simmons AJ, Andrae U and others (2005) The ERA-40 reanalysis. QJR Meteorol Soc 131: 2961-3012

Webster PJ, Magana VO, Palmer TN, Shukla J, Tomas RA, Yanai M, Yasunari T (1998) Monsoons: processes, predictability, and the prospects for prediction. J Geophys Res 103:14451-14510

Submitted: October 30, 2008; Accepted: June 16, 2009

Proofs received from author(s): September 4, 2009 